\title{
Phosphate salt bowel preparation regimens alter perioperative acid-base and electrolyte balance
}

\author{
[Les préparations intestinales aux sels phosphatés modifient l'équilibre \\ périopératoire acide-base et électrolytique]
}

Tiberiu Ezri MD, ${ }^{*} \dagger$ Emma Lerner MD, $\ddagger$ Michael Muggia-Sullam MD, $\$$ Benjamin Medalion MD, $\mathbb{I}$ Alexander Tzivian MD, Abraham Cherniak MD, ${ }^{* *}$ Peter Szmuk MD, †† Mordechai Shimonov MD $\ddagger$

Background: Hyperphosphatemic acidosis and severe electrolyte disturbances caused by phosphate salts $(\mathrm{PO})$ used for mechanical bowel preparation have been described in occasional case reports prior to bowel resection surgery. We hypothesized that $\mathrm{PO}$ used preoperatively for bowel preparation may cause more pronounced acid base and electrolyte changes than polyethylene glycol (PG).

Methods: Forty American Society of Anesthesiologists physical status II-III patients were randomly allocated to receive either PO or PG for bowel preparation before intra-abdominal surgery (bowel resection or other major elective intra-abdominal surgeries). Measurements of $\mathrm{pH}$, base deficit, blood gases, lactate, hemoglobin, calcium, magnesium, potassium and phosphorus were undertaken before the laxative administration, intraoperatively, and postoperatively.

Results: Preoperative demographic, hemodynamic and laboratory data were similar in the two groups. Intraoperative calcium (8.4 [0.6] vs 9 [0.5] $\left.\mathrm{mg} \cdot \mathrm{dL}^{-1}\right)$ and $\mathrm{pH}(7.35$ [0.04] vs 7.4I [0.03]) were lower, while lactate $\left(1.3[0.4]\right.$ vs $\left.0.9[0.3] \mathrm{mmol} \cdot \mathrm{L}^{-1}\right)$ was higher with $\mathrm{PO}$. Postoperative calcium, magnesium and potassium were lower $\left(8[0.5]\right.$ vs $8.9[0.2] \mathrm{mg} \cdot \mathrm{dL}^{-1}, \mathrm{I} .68[0.3]$ vs $\mathrm{I} .8$ [0.4] and $3.5[0.36]$ vs $3.7[0.33] \mathrm{mEq} \cdot \mathrm{L}^{-1}$ respectively) while phosphorus (4.I [0.3] vs 3.3 [0.2] $\mathrm{mEq} \cdot \mathrm{L}^{-1}$ ) was higher with PO. A higher percentage of abnormal values for calcium, potassium, phosphorus and base deficit (66\% vs $33 \%$, $25 \%$ vs $10 \%$, $19 \%$ vs $2 \%$ and $28.3 \%$ vs $5 \%$ respectively) were observed with PO.

Conclusions: Calcium and magnesium changes were more pronounced in patients who received PO for bowel preparation.
Objectif : L'acidose hyperphosphatémique et des troubles sévères des électrolytes causés par les sels phosphatés (PO) utilisés pour la préparation intestinale mécanique ont été décrits à l'occasion dans des présentations de cas avant la résection de l'intestin. Nous avons supposé que les PO utilisés avant l'opération pour la préparation intestinale pouvaient causer plus de changements acide base et électrolytiques que le polyéthylèneglycol (PG).

Méthode : Quarante patients d'état physique ASA II-III ont reçu au hasard soit des PO, soit du PG pour la préparation de l'intestin à la chirurgie intra-abdominale comme la résection de l'intestin ou d'autres opérations majeures réglées. Les mesures du pH, du déficit basique, des gaz sanguins, du lactate, de l'hémoglobine, du calcium, du magnésium, du potassium et du phosphore ont été faites avant l'administration du laxatif, pendant et après l'opération.

Résultats: Les données démographiques, hémodynamiques et de laboratoire étaient similaires dans les deux groupes. Le calcium $\left(8,4[0,6]\right.$ vs $\left.9[0,5] \mathrm{mg} \cdot \mathrm{dL}^{-1}\right)$ et le $\mathrm{pH}(7,35[0,04]$ vs $7,4$ I $[0,03])$ peropératoires étaient plus bas, mais le lactate $\left(I, 3[0,4]\right.$ vs $\left.0,9[0,3] \mathrm{mmol} \cdot \mathrm{L}^{-1}\right)$ était plus élevé avec le $P O$. Le calcium, le magnésium et le potassium postopératoires ont été plus bas $\left(8[0,5]\right.$ vs $8,9[0,2] \mathrm{mg} \cdot \mathrm{dL}^{-1}, 1,68[0,3]$ vs $1,8[0,4]$ et $3,5[0,36]$ vs $\left.3,7[0,33] \mathrm{mEq} \cdot \mathrm{L}^{-1}\right)$ tandis que le phosphore $(4,1$ $[0,3]$ vs $3,3[0,2] \mathrm{mEq} \cdot \mathrm{L}^{-1}$ ) a été plus élevé avec le $P O$. Un plus fort pourcentage de valeurs anormales pour le calcium, le potassium, le phosphore et le déficit basique (66 \% vs $33 \%, 25 \%$ vs $10 \%, 19 \%$ vs $2 \%$ et $28,3 \%$ vs $5 \%$ a été observé avec le $P O$. Conclusion : Les changements notés pour le calcium et le magnésium étaient plus prononcés chez les patients qui ont reçu des $P O$ pour une préparation intestinale.

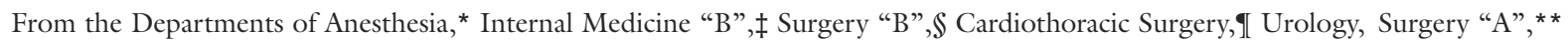
Anesthesiology, †† The University of Texas Medical School at Houston, TX; Surgery "A", $\ddagger$ Wolfson Medical Center, Holon, Affiliated to Sackler School of Medicine, Tel Aviv University, Israel; and the Outcomes Research ${ }^{\mathrm{TM}}$ Institute, $†$ University of Louisville, Kentucky, USA. Address correspondence to: Dr. Peter Szmuk, Department of Anesthesiology, The University of Texas Medical School at Houston, 6431

Fannin, MSB 5.020, Houston, Texas 77030, USA. E-mail: peter.szmuk@uth.tmc.edu Accepted for publication July 13, 2005

Revision accepted September 9, 2005. 
M

ETABOLIC acidosis may occur following major abdominal surgery (bowel resection, pancreatectomy, etc.) and may be caused by multiple mechanisms: "dilution" acidosis due to infusion of large volumes of saline solution, ${ }^{1,2}$ lactic acidosis due to hypovolemia and/or low perfusion state (i.e., prolonged organ ischemia, decreased lactate metabolism by liver) and ketoacidosis due to either prolonged fasting, ${ }^{3}$ alcohol intoxication $^{4}$ or diabetes. A rare reason for perioperative acidosis is hyperphosphatemia.

Hyperphosphatemic acidosis caused by phosphate salts (PO) used for mechanical bowel preparation has been described in occasional case reports prior to bowel resection surgery. ${ }^{5}$ However, this problem is often overlooked by many physicians. ${ }^{6}$

Even in volumes as low as $90 \mathrm{~mL}, \mathrm{PO}$ administration for bowel preparation may be associated with severe metabolic disorders (i.e., severe hyperphosphatemic acidosis), coma, hypovolemia, serious electrolyte disturbances including hyperphosphatemia, hypokalemia, hypomagnesemia, hypocalcemia (tetany has been described), hypernatremia, acute renal failure or even death. ${ }^{5,7-11}$ These disturbances are aggravated by preexisting congestive heart failure, renal function impairment, liver failure and slow bowel elimination therefore, in these patients, the use of polyethylene glycol (PG) instead of PO is indicated. ${ }^{11,12}$

We hypothesized that PO used preoperatively for bowel preparation may cause more pronounced acid base and electrolyte changes than PG.

\section{Methods}

The study was conducted at the Wolfson Medical Center. The Institutional Review Board Committee approval and each patient's informed consent were obtained before starting the study.

Primary outcomes of the study were perioperative changes in the two groups in base excess/deficit, $\mathrm{pH}$, lactate, phosphate, calcium, magnesium and potassium serum levels during all time point measurements.

The sample size for this study was calculated as follows: although the apparent magnitude of change in acid base and electrolyte balance that might be considered to be problematic and clinically relevant would be any value which is higher or lower that the normal range of values, we defined a difference between groups of $5 \mathrm{mEq} \cdot \mathrm{L}^{-1}$ for sodium, 0.05 units for $\mathrm{pH}$, $5 \mathrm{mEq} \cdot \mathrm{L}^{-1}$ for base excess/deficit, $0.5 \mathrm{mmol} \cdot \mathrm{L}^{-1}$ for lactate, $0.3 \mathrm{mEq} \cdot \mathrm{L}^{-1}$ for magnesium, $0.5 \mathrm{mEq} \cdot \mathrm{L}^{-1}$ for potassium, $0.5 \mathrm{mg} \cdot \mathrm{dL}^{-1}$ for serum inorganic phosphorus and $1 \mathrm{mg} \cdot \mathrm{dL}^{-1}$ for total serum calcium, to be clinically important. This is because we considered that the trend of change itself and the amount of change and not only the absolute value is also important. To achieve an $80 \%$ power to detect such a difference with an $\alpha$ of $0.05,17$ patients were required in each group. To account for possible incomplete data acquisition, we therefore enrolled 20 patients per group (age $\geq 40$ yr); subjects undergoing elective open bowel resection or other major elective intra-abdominal surgeries, which per routine necessitate bowel preparation.

Excluded from the study were patients with preexisting metabolic acidosis that was diagnosed before the bowel preparation (i.e., renal failure induced metabolic acidosis), decompensated congestive heart failure, impaired renal function (i.e., serum creatinine $>1.5 \mathrm{mg} \cdot \mathrm{dL}^{-1}$ ), liver failure or other reasons for hyperphosphatemia (i.e., rabdomyolysis, tumour lysis, etc.). Under these circumstances, phosphate administration is contraindicated.

Patients were fasted from the night before surgery; however, on the morning of surgery, they were allowed to take their usual medications (i.e., antihypertensive drugs) with a sip of water.

In a prospective, single blind trial, 40 patients were randomly allocated with the closed envelope method to two study groups of 20 patients each, according to the type of regimen used for bowel preparation: group PG received bowel preparation with oral PG solution $(2,700 \mathrm{~mL}$ total volume - one glass every ten minutes) and those in group $\mathrm{PO}$ received oral sodium phosphate solution two flacons $(90 \mathrm{~mL})$ as cathartic, and additional water as prescribed. The bowel preparation treatment was randomly ordered and carried out the night before surgery by the surgeon on call, who was not involved with the study. The anesthesiologist in charge of the blood sampling was "blinded" to the type of bowel treatment the patient received. Patients continued to have oral fluids until 12 p.m. the night before surgery. On the morning of surgery, iv lactated Ringer's solution was started at a rate of $100 \mathrm{~mL} \cdot \mathrm{hr}^{-1}$ as maintenance fluid therapy.

In diabetic patients the preoperative blood glucose was kept between 100 to $200 \mathrm{mg} \cdot \mathrm{dL}^{-1}$.

Anesthesia induction and maintenance were standardized: midazolam $1 \mathrm{mg}$ iv, fentanyl $1 \mu \mathrm{g} \cdot \mathrm{kg}^{-1}$ iv prior to induction (and then, aliquots of $50 \mu \mathrm{g}$ in as required), thiopental - "sleep" dose, rocuronium (provided bowel obstruction was ruled-out, in which case succinylcholine was employed for intubation in a rapid sequence manner), isoflurane (0.5 - 1.5 MAC) and $60 \% \mathrm{~N}_{2} \mathrm{O}$ in oxygen. Intraoperatively, all patients were ventilated in a volume mode (tidal volume 7 $\mathrm{mL} \cdot \mathrm{kg}^{-1}$ and respiratory rate 10 breaths $\cdot \mathrm{min}^{-1}$ ).

In addition to routine monitoring, direct arterial pressure, central venous pressure, urine out- 
put and nasopharyngeal temperature were measured. Hypothermia was avoided with fluid warmers and forced - air warmers from the moment the patient was brought into the operating room. Patient's tracheas were extubated according to standard criteria, when hemodynamically stable, ongoing surgical bleeding was excluded, core temperature was $>35^{\circ} \mathrm{C}$ and arterial $\mathrm{pH}>7.20$. Fluid input was standardized in both groups. Patients received lactated Ringer's solution at a rate of $10 \mathrm{~mL} \cdot \mathrm{kg}^{-1} \cdot \mathrm{hr}^{-1}$ (including fasting, intraoperative maintenance and third spacing). Blood was transfused according to the American Society of Anesthesiologists guidelines ${ }^{13}$ which state that blood transfusion is rarely indicated when the hemoglobin $(\mathrm{Hb})$ concentration is $>10 \mathrm{~g} \cdot \mathrm{dL}^{-1}$ and is almost always indicated when it is $<6 \mathrm{~g} \cdot \mathrm{dL}^{-1}$, especially when the anemia is acute. The determination of whether $\mathrm{Hb}$ concentrations of 6 to $10 \mathrm{~g} \cdot \mathrm{dL}^{-1}$ justify blood transfusion was based on the patient's risk for complications of inadequate oxygenation (i.e., we tried to keep $\mathrm{Hb}$ at $10 \mathrm{~g} \cdot \mathrm{dL}^{-1}$ or higher in patients suffering from ischemic heart disease).

Postoperative fluid replacement consisted of lactated Ringer's solution $100 \mathrm{~mL} \cdot \mathrm{hr}^{-1}$, and if necessary, blood and fluid boluses were administered according to the above criteria. Diabetic patients with a blood glucose $>200 \mathrm{mg} \cdot \mathrm{dL}^{-1}$ received a $5 \%$ glucose solution with a continuous infusion of insulin given at a rate of $2 \mathrm{IU} \cdot 100 \mathrm{~mL}^{-1} \cdot \mathrm{hr}^{-1}$. Potassium was added with a serum level $<3.5 \mathrm{mEq} \cdot \mathrm{L}^{-1}$. Postoperatively, patients were managed in the postanesthesia care unit for at least four hours.

\section{Measurements}

Arterial blood samples were drawn in a preheparinized syringe. Standard bicarbonate, base deficit or excess, $\mathrm{pH}, \mathrm{PaCO}_{2}, \mathrm{PaO}_{2}, \mathrm{Hb}$, serum lactate, inorganic phosphorus, calcium (total), magnesium, chloride, sodium, potassium, urea, and glucose were analyzed before starting the bowel preparation (baseline), every hour during surgery and one, eight and $24 \mathrm{hr}$ postoperatively. Measurements were performed with the Olympus Au 2700 analyzer system for clinical chemistry (Olympus Diagnostica GmbH, Hamburg, Germany). Mean arterial pressure, heart rate, central venous pressure, urine output and temperature were recorded at the same time points.

\section{Data analysis}

We performed a univariate analysis, where continuous variables with distribution significantly differing from normal were compared using the Mann-Whitney U or median tests. Categorical data were described using frequency counts and percentages and compared using Chi-square (with Yates correction) or Fisher's exact tests, as appropriate. We performed two multivariable analyses. Both were repeated measure general linear models. In the first multivariable analysis, the effect of study group, total fluid administered (which may affect by dilution the electrolytes measurements), age and sex were studied as predictors for changes in phosphorus, magnesium, calcium and potassium. In the second multivariable analysis, study group, total volume of lactated Ringer's solution, normal saline infused and diabetes (all three, potentially affecting the acid-base balance) were analyzed as predictors for changes in $\mathrm{pH}$, base excess/deficit and lactate. Secondary outcomes (during all time point measurements) were a need for mechanical ventilation due to a $\mathrm{pH}<7.20$ and any complication related to acidosis or electrolyte disturbances (i.e., arrhythmias). The effect of study group, age, sex, and amount of fluid administered, on the outcome variables were also studied.

Data analysis was performed using the SPSS for Windows (SPSS Inc, Chicago, IL, USA). All tests were considered significant at $P<0.05$.

\section{Results \\ Preoperative data}

Patients were scheduled for open intra-abdominal surgeries including bowel resection for tumours and radical prostatectomy. Demographic data presented in Table I were similar between groups. The incidence of ischemic heart disease, hypertension and hyperlipidemia was similar, as was the American Society of Anesthesiologists physical status. Preoperative hemodynamic and laboratory data were also similar (Tables I and II).

\section{Intraoperative data}

Duration of surgery, the amount of intraoperative fluid and blood administered, and urinary output were similar (Table I). Intraoperative hemodynamic data were also similar at corresponding times (Table II). The laboratory data with significant differences between the groups are presented in Table III.

Intraoperative calcium and $\mathrm{pH}$ were lower, while base deficit and lactate were higher in the PO group (Table III). At the end of surgery the sodium, chloride, urea, glucose, arterial blood $\mathrm{PaCO}_{2}$ and arterial blood $\mathrm{PaO}_{2}$ were normal and similar between the groups (data not presented). Hemoglobin was $11.8 \pm$ l ps $11.3 \pm 1 \mathrm{mg} \cdot \mathrm{dL}$. 
TABLE I Demographic data

\begin{tabular}{|c|c|c|c|}
\hline $\begin{array}{l}\text { Group } \\
\text { Variable }\end{array}$ & $\begin{array}{l}\text { Sodium } \\
\text { phosphate }\end{array}$ & $\begin{array}{l}\text { Polyethylene } \\
\text { glycol }\end{array}$ & $P$ \\
\hline Age (yr) & $64.7(9)$ & $67.9(9)$ & NS \\
\hline $\operatorname{Sex}(\%)$ & & & NS \\
\hline Male & 45 & 40 & \\
\hline Female & 55 & 60 & \\
\hline \multirow[t]{3}{*}{ ASA class (\%) } & & & NS \\
\hline & II $(70)$ & II $(75)$ & \\
\hline & III $(30)$ & III $(25)$ & \\
\hline Smoking (\%) & 50 & 40 & NS \\
\hline Hypertension (\%) & 30 & 36.8 & NS \\
\hline Ischemic heart disease (\%) & 30 & 47 & NS \\
\hline Diabetes (\%) & 45 & 50 & NS \\
\hline Hyperlipidemia (\%) & 25 & 5 & NS \\
\hline $\begin{array}{l}\text { Intraoperative lactated } \\
\text { Ringer's infused (mL) }\end{array}$ & $4,400(1,500)$ & $4,500(1,000)$ & NS \\
\hline $\begin{array}{l}\text { Intraoperative transfusion } \\
\text { (\% of patients) }\end{array}$ & 20 & 25 & NS \\
\hline $\begin{array}{l}\text { Volume transfused in } \\
\text { patients who received } \\
\text { blood }(\mathrm{mL})\end{array}$ & $925(65)$ & $1087(487)$ & NS \\
\hline Duration of surgery $(\mathrm{min})$ & $205(86)$ & $188(61)$ & NS \\
\hline
\end{tabular}

ASA $=$ American Society of Anesthesiologists; NS = not significant. Results are expressed as means (SD) and percentage.
TABLE II Intraoperative hemodynamics, urine output and temperature

\begin{tabular}{|c|c|c|c|}
\hline $\begin{array}{l}\text { Group } \\
\text { Variable }\end{array}$ & $\begin{array}{l}\text { Sodium } \\
\text { phosphate }\end{array}$ & $\begin{array}{l}\text { Polyethylene } \\
\text { glycol }\end{array}$ & $P$ \\
\hline \multicolumn{4}{|l|}{$\mathrm{MAP}(\mathrm{mmHg})$} \\
\hline Preinduction & $98(15)$ & $102(11)$ & NS \\
\hline - 20 min postinduction & $69(17)$ & $63(7)$ & NS \\
\hline - $1 \mathrm{hr}$ intraoperative & $70(17)$ & $76(8)$ & NS \\
\hline$-2 \mathrm{hr}$ intraoperative & $80(20)$ & $84(10)$ & NS \\
\hline - *End of surgery & $86(10)$ & $88(12)$ & NS \\
\hline \multicolumn{4}{|l|}{ HR (beats. $\min ^{-1}$ ) } \\
\hline - Preinduction & $86(12)$ & $88(10)$ & NS \\
\hline - 20 min postinduction & $80(10)$ & $77(17)$ & NS \\
\hline - $1 \mathrm{hr}$ intraoperative & $77(13)$ & $79(7)$ & NS \\
\hline - $2 \mathrm{hr}$ intraoperative & $78(10)$ & $76(8)$ & NS \\
\hline$-{ }^{*}$ End of surgery & $84(15)$ & $86(12)$ & NS \\
\hline \multicolumn{4}{|l|}{$\mathrm{CVP}(\mathrm{mmHg})$} \\
\hline - 20 min postinduction & $10(4)$ & $9(2.5)$ & NS \\
\hline - $1 \mathrm{hr}$ intraoperative & $12(4)$ & $11(2)$ & NS \\
\hline - $2 \mathrm{hr}$ intraoperative & $11(2)$ & $11(2)$ & NS \\
\hline - * end of surgery & $10(4)$ & $9(3)$ & NS \\
\hline $\begin{array}{l}\text { Intraoperative urine } \\
\text { output }(\mathrm{mL})\end{array}$ & $334(134)$ & $306(58)$ & NS \\
\hline \multicolumn{4}{|l|}{ Temperature $\left({ }^{\circ} \mathrm{C}\right)$} \\
\hline - start of surgery & $36.3(0.3)$ & $36.4(0.2)$ & NS \\
\hline - end of surgery & $36.7(0.2)$ & $36.6(0.1)$ & NS \\
\hline
\end{tabular}

Although most of the averages were within the normal range, temporal changes in $\mathrm{pH}$, base deficit, lactate, calcium and magnesium occurred within the two groups. Calcium and magnesium changed significantly between the two groups. No patient had a $\mathrm{pH}<7.20$, which would have mandated postoperative mechanical ventilation according to the protocol. No complications related to acidosis or electrolyte changes were observed.

\section{Discussion}

Bowel preparation is routine in many abdominal surgeries. The preoperative preparation generally includes mechanical cleansing and antibiotic administration. The approach for mechanical cleansing had changed during recent years, from a three-day regimen consisting of low residual diet combined with laxatives and enemas, to a one-day regimen of isotonic solutions containing balanced salt solution such as PG, or sodium phosphate preparations like PO. ${ }^{14}$

A major impediment to efficient bowel preparation is noncompliance of patients. Although well tolerated by the patients, sodium PO solutions carry the risk of electrolyte disturbances that can aggravate preexisting renal or liver failure or reciprocally, the above mentioned preexisting diseases might aggravate the toxicbetween groups (Table III). 
TABLE III Univariate and multivariable analysis of laboratory data*

\begin{tabular}{|c|c|c|c|c|}
\hline \multicolumn{4}{|l|}{ Variable } & $P$ values \\
\hline Serum potassium $1 \mathrm{hr}$ postoperative $\left(\mathrm{mEq} \cdot \mathrm{L}^{-1}\right)$ & $3.5(0.4)$ & $3.7(0.3)$ & $3.5-5.1$ & 0.04 \\
\hline \multicolumn{3}{|l|}{ Serum magnesium $-\left(\mathrm{mEq} \cdot \mathrm{L}^{-1}\right)$} & $1.3-2.1$ & \\
\hline - 1 hr postoperative & $1.6(0.3)$ & $1.8(0.4)$ & & 0.028 \\
\hline - $8 \mathrm{hr}$ postoperative & $1.7(0.3)$ & $1.9(0.3)$ & & 0.04 \\
\hline \multicolumn{3}{|l|}{ Total serum calcium $\left(\mathrm{mg} \cdot \mathrm{dL}^{-1}\right)$} & $8.4-10.2$ & \\
\hline - 1 hr postoperative & $8(0.5)$ & $8.7(0.5)$ & & 0.0001 \\
\hline - $8 \mathrm{hr}$ postoperative & $8(0.5)$ & $8.9(0.2)$ & & 0.0001 \\
\hline Postoperative serum inorganic phosphorus $\left(\mathrm{mg} \cdot \mathrm{dL}^{-1}\right)$ & $4.1(0.3)$ & $3.3(0.2)$ & $2.7-4.5$ & 0.03 \\
\hline \multicolumn{5}{|l|}{ Arterial lactate $\left(\mathrm{mmol} \cdot \mathrm{L}^{-1}\right)$} \\
\hline - $1 \mathrm{hr}$ intraoperative & $1.3(0.4)$ & $0.9(0.3)$ & $0.5-1.6$ & 0.003 \\
\hline \multicolumn{3}{|l|}{ Arterial pH } & $7.35-7.45$ & \\
\hline - $1 \mathrm{hr}$ intraoperative & $7.38(0.04)$ & $7.40(0.02)$ & & 0.045 \\
\hline \multicolumn{3}{|l|}{ Arterial base excess/deficit $\left(\mathrm{mEq} \cdot \mathrm{L}^{-1}\right)$} & $-2+3$ & \\
\hline - 1 hr intraoperative & $-1.5(0.3)$ & $-0.6(0.2)$ & & 0.003 \\
\hline - 2 hr Intraoperative & $-2.3(0.5)$ & $-0.9(0.3)$ & & 0.003 \\
\hline \multicolumn{5}{|l|}{ Multivariable analysis } \\
\hline \multicolumn{4}{|c|}{ - Within group temporal changes of $\mathrm{pH}$, base deficit and lactate } & 0.005 \\
\hline \multicolumn{4}{|c|}{ - Within group temporal changes of calcium and magnesium } & 0.01 \\
\hline \multicolumn{4}{|l|}{ - Between groups changes in calcium and magnesium } & 0.05 \\
\hline
\end{tabular}

*Only statistically significant data are presented.

ity caused by the PO. ${ }^{11,12}$ We did not assess patient compliance with either preparation.

Our study demonstrated significant temporal changes in $\mathrm{pH}$, base deficit, lactate, calcium and magnesium within the two groups. Calcium and magnesium changed significantly between the two groups. Although both preparations produce their cathartic activity by osmotic effect in the gut with a shift of fluid and electrolytes across the gut wall into the gut lumen, the probability of electrolyte disturbances differs.

Tan et al. ${ }^{8}$ reported six cases of severe electrolyte and metabolic derangements due to sodium phosphate bowel preparation: two patients had delayed awakening from general anesthesia, and four patients suffered life-threatening consequences. We did not encounter any delay in recovery from anesthesia, nor was there any life-threatening complication. This may be explained by the short-term bowel preparation of our patients, as well as the rigorous intraoperative hemodynamic monitoring and fluid replacement.

We found that the use of PO may alter the normal acid base balance of the patients more than with PG. In the $\mathrm{PO}$ group, $\mathrm{pH}$ values and base excess were significantly lower compared to the PG group (Table III). This difference cannot be explained by any single intraoperative event, considering that the fluid input and urine output where not different. Hill et al. ${ }^{15}$ demonstrated that patients treated with oral sodium

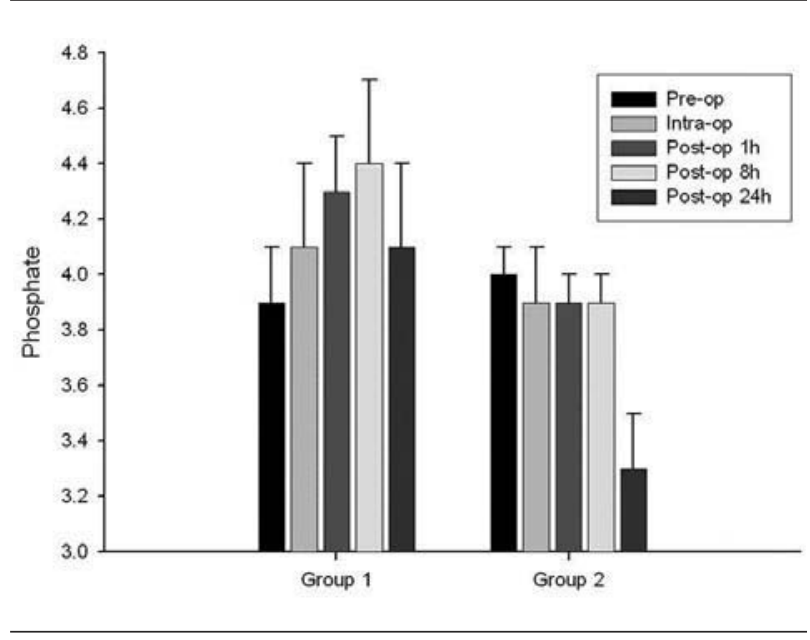

FIGURE Perioperative serum inorganic phosphorus measurements. Group 1 = patients treated with sodium phosphate; Group 2 = patients treated with polyethylene glycol.

phosphate have depleted intracellular potassium. These patients are at risk of hypokalemia after this treatment. Others have described that the occurrence of hyperphosphatemia, hypocalcemia, hypomagnesemia and hypokalemia was common with the use of $\mathrm{PO}$ rather than with $\mathrm{PG}^{8-10}$ In our series, the preoperative electrolyte status of the patients in both groups was simi- 
lar. However, the persistent decrease in postoperative magnesium is related to the use of PO. This was also the case with the calcium, which resulted in a similar decreasing pattern during the first eight postoperative hours. Postoperative potassium levels were also lower in the PO group. In contrast to what was anticipated, hyperphosphatemia was not observed, presumably due to exclusion from the study of patients with heart, kidney and liver failure in whom hyperphosphatemia has been repeatedly reported following administration of PO. ${ }^{11,12}$

The changes in electrolytes were not long lasting, as they returned to normal $24 \mathrm{hr}$ after surgery. Although we encountered significantly more pronounced perioperative acid-base balance and electrolyte changes in patients who received sodium phosphate for bowel preparation before abdominal surgery, there were no complications related to those changes in either of the groups.

In a study of carefully selected elderly patient groups comparing PO with PG before colonoscopy, Thomson et al. ${ }^{16}$ concluded that sodium phosphate was a safe and effective bowel preparation, in spite of transient, mild changes in serum phosphorus and potassium.

One limitation of our study is that we cannot extrapolate our results to a high-risk patient group. However, it would be unethical to undertake such a study in at risk populations (patients suffering from heart, renal and hepatic failure), considering that the use of sodium phosphate solutions is contraindicated in those patients.

We conclude that in patients requiring bowel preparation prior to abdominal surgery, temporal changes in $\mathrm{pH}$, base deficit, lactate, calcium and magnesium occurred within the sodium phosphate and polyethylene glycol groups. Calcium and magnesium changes were more pronounced in the sodium phosphate group.

\section{References}

1 Waters JH, Miller LR, Clack S, Kim JV. Cause of metabolic acidosis in prolonged surgery. Crit Care Med 1999; 27: 2142-6.

2 Waters JH, Gottlieb A, Schoenwald P, Popovich MJ, Sprung J, Nelson DR. Normal saline versus lactated Ringer's solution for intraoperative fluid management in patients undergoing abdominal aortic aneurysm repair: an outcome study. Anesth Analg 2001; 93: 817-22.

3 Valencia I, Pfeifer H, Thiele EA. General anesthesia and the ketogenic diet: clinical experience in nine patients. Epilepsia 2002; 43: 525-9.
4 Hitender J, Sushil B, Shailender S. Alcohol induced ketoacidosis, severe hypoglycemia and irreversible encephalopathy. Med Sci Monit 2002; 8: 77-9.

5 Pitcher DE, Ford RS, Nelson MT, Dickinson WE. Fatal hypocalcemic, hyperphosphatemic, metabolic acidosis following sequential sodium phosphate-based enema administration. Gastrointest Endosc 1997; 46: 266-8.

6 Hookey LC, Depew WT, Vanner $S$. The safety profile of oral sodium phosphate for colonic cleansing before colonoscopy in adults. Gastrointest Endosc 2002; 56: 895-902.

7 Markowitz GS, Nasr SH, Klein P, et al. Renal failure due to acute nephrocalcinosis following oral sodium phosphate bowel cleansing. Hum Pathol 2004; 35: 675-84.

8 Tan HL, Liew QY, Loo S, Hawkins R. Severe hyperphosphataemia and associated electrolyte and metabolic derangement following the administration of sodium phosphate for bowel preparation. Anaesthesia 2002; 57: 478-83.

9 Shaoul R, Wolff R, Seligmann H, Tal $\Upsilon$, Jaffe M. Symptoms of hyperphosphatemia, hypocalcemia, and hypomagnesemia in an adolescent after the oral administration of sodium phosphate in preparation for a colonoscopy. Gastrointest Endosc 2001; 53: 650-2.

10 Lieberman DA, Ghormley J, Flora K. Effect of oral sodium phosphate colon preparation on serum electrolytes in patients with normal serum creatinine. Gastrointest Endosc 1996; 43: 467-9.

11 Nir-Paz R, Cohen R, Haviv YS. Acute hyperphosphatemia caused by sodium phosphate enema in a patient with liver dysfunction and chronic renal failure. Ren Fail 1999; 21: 541-4.

12 Ferguson KH, Neil JJ, Morey AF. Mechanical and antibiotic bowel preparation for urinary diversion surgery. J Urol 2002; 167: 2352-6.

13 Practice guidelines for blood component therapy: a report by the American Society of Anesthesiologists Task Force on blood component therapy. Anesthesiology 1996; 84: 732-47.

14 Rubesin SE, Levine MS, Laufer I, Herlinger H. Doublecontrast barium enema examination technique. Radiology 2000; 215: 642-50.

15 Hill AG, Teo W, Still A, Parry BR, Plank LD, Hill GL. Cellular potassium depletion predisposes to hypokalaemia after oral sodium phosphate. Austr N Z J Surg 1998; 68: 856-8.

16 Thomson A, Naidoo P, Crotty B. Bowel preparation for colonoscopy: a randomized prospective trail comparing sodium phosphate and polyethylene glycol in a predominantly elderly population. J Gastroenterol Hepatol 1996; 11: 103-7. 